\title{
Orientals Need Apply: Gender-Based Asylum in the U.S.
}

\section{Midori Takagi \\ Western Washington University}

Every other year I teach a course entitled "The History of Asian Women in America," which focuses on the experiences of East, South and Southeast Asian women as they journey to these shores and resettle. Using autobiographies, poetry, journal writings, interviews and academic texts, the students learn from the women what political, social, cultural, economic and ecological conditions prompted them to leave their homelands and why they chose the United States. We learn of their rich cultural backgrounds, their struggles to create a subculture based on their home and host experiences, and the cultural gaps that often appear between the first and subsequent generations. And we also learn how patriarchy affects their lives transnationally. In spite of all this information, inevitably one student always asks "why are Asian cultures so oppressive to women?"

I always cringe when this question is asked because it reveals, among other things, the pervasiveness of "Orientalism:" an ideological view of the East as being dark, mysterious, chaotic, feared, and in need of governance; 
and the persistence of American Exceptionalism: the notion of a U.S. that is civilized, powerful, and has the "God-given" right to govern the East. ${ }^{1}$ No matter what or how I teach, it is very difficult to dislodge these ideological, ethnocentric, and racialized patriarchal beliefs.

As a result, I find myself struggling to write this article on Asian women and asylum, as I reflect on concepts of nonrefoulement (not being forcibly returned to one's country of origin if it is unsafe), universal human rights, and providing protection to vulnerable groups, alongside the occurrences of honor and dowry killings, forced abortions, female genital mutilations, and domestic violence. I believe if I were to write about gender-based asylum solely within the context of these categories, I would inevitably reinforce the notion of America as the bastion of liberal freedom, and of Asia as a fortress of tradition and hierarchy.

A simple reading of Aruna C. Vallabhaneni's asylum case, for example, can easily serve as damning evidence of an allegedly callous and misogynistic Indian culture. Vallabhaneni sought asylum in the United States after suffering fourteen years of abuse at the hands of her husband, which included two attempted murders and "repeated blows to the stomach which resulted in a hysterectomy." The one time the husband was arrested, Vallabhaneni's father arranged for his release, cancelled his daughter's complaint and forced her to return home to her abuser. Not only did Vallabhaneni's parents know of the abuse, and refused to help they also warned should she contact the police again, "their reputation would be ruined...and they would commit suicide out of shame."2

If I were writing the legal brief, I would certainly emphasize the cruelty of Vallabhaneni's husband and of her family, but also the depraved indifference of the state and societal norms. And in examining the legal documents of other notable asylum cases, I find these very tactics have been used to prove gender-based persecution. In Re: Fauziya Kasinga $a^{3}$ (1996), for example, the case concern- 
ing an eighteen-year old West African native who fled to the United States to escape forced female circumcision, attorney Karen Musalo presented U.S. State Department reports to demonstrate how commonplace it is for Togolese women to "suffer extensive discrimination," from the cruel local practices such as forced marriages and female genital mutilation (FGM). ${ }^{4}$

I find no fault with Musalo or any other attorney who works to protect women seeking safety from violence. I believe that in nearly all countries, including the United States, beliefs and practices are used to undermine, if not negate, ideals of gender equality and deny women the ability to control their bodies and their labor. I also believe the women who flee their abusers have suffered extreme violence at the hands of their families and of the state. But I also know that non-western cultures, and specifically Asian cultures (for the purposes of this article) are not necessarily antithetical to individual rights and gender equality. Yet an examination of the asylum process-and perhaps immigration adjudication overall-demonstrates there is little room for any other reading aside from indicting Asian cultures and lauding the freedoms of American life and its supposedly moral superiority.

This article examines gender-based asylum cases to demonstrate how the very process itself is structured by ethnocentric and racialized gendered ideals that are rooted in assumptions about the "Orient" as monolithic and motivated solely by dangerous religious and cultural identities, and the U.S. as rational, constitutionally-bound, with a clear separation between church and state. And with every new successful gender-related asylum case, these ideals and assumptions become further entrenched.

A person who applies for asylum must meet two basic requirements: they must be on U.S. soil and they cannot return to their homelands for fear of persecution based on "reasons of race, religion, nationality, membership of a particular social group or political opinion...." The lat- 
ter asylum requirement is actually the legal definition of a refugee originally adopted from the 1951 United Nations Refugee Convention Relating to the Status of Refugees and the 1967 Protocol. 6 The former requirement was created in 1952 through the Immigration and $\mathrm{Na}$ tionality Act, to help shield refugees already present on U.S. land from being deported. ${ }^{7}$ While the definition and requirements seem simple and straightforward, applying them to real-live cases has proved to be very difficult; gender, for example, is never mentioned, which made it extremely problematic for women to demonstrate gender-related persecution, which will be discussed shortly.

Little changed in the asylum process since the 1950s until Congress passed the 1980 Refugee Act, which is the foundation for the present program. This new act created a "systematic procedure" with "comprehensive and uniform provisions," for the admissions of asylees. ${ }^{8}$ Petitioners, regardless of how they arrived to the U.S., meet with an asylum officer who has the ability to approve their application. Should the officer deny the application, which places the petitioner in jeopardy of being deported, the case is then referred to an Immigration Judge (IJ) who can decide to withhold removal and grant asylum. Should the petitioner still be denied, they can appeal their case to the Board of Immigration Appeals (BIA) and if necessary have it reviewed in a U.S. Court of Appeals. ${ }^{9}$

It was not until 1995 did the Immigration and Naturalization Service (INS) acknowledge that women refugees have experiences that are particular to their gender and recommended changes. ${ }^{10}$ That year they introduced new guidelines to help asylum officers evaluate claims. These guidelines included information on rape, mass rape, sexual abuse, domestic violence and on societal conditions that make women vulnerable to abuse. They also posted reasons as to why women might not speak of their experiences or may be reluctant to disclose information to male interviewers. Finally, the guidelines reminded officers 
to be sensitive to cross-cultural differences particularly when assessing the credibility of the applicant in terms of demeanor and speech; women who have experienced great trauma may not maintain eye contact, may suffer from memory loss or show no emotion. ${ }^{11}$

These guidelines signaled a significant change in attitudes that gave hope to immigrants', women's and human rights' organizations internationally. Applicants and their attorneys, along with activists took this opportunity to help push the guidelines into standard practices through case law. In 1996, for example, Fauziya Kasinga helped set the standard for asylum cases based on female genital mutilation. ${ }^{12}$ That same year, a petitioner from China helped pave the way for women seeking safety from forced abortions and sterilizations. ${ }^{13}$ And in 2009, after a lengthy legal battle, Rodi Alvarado Peña helped clear a path for applications based on domestic violence. ${ }^{14}$

But even with these new guidelines, the chances of women receiving gender-related asylum have been extremely unpredictable. Rodi Alvarado Peña, mentioned above, endured a thirteen-year legal battle before she was granted asylum. In her case, the IJ, in 1996, decided in her favor, but INS appealed the case and the BIA reversed the judge's decision. Later, Attorney General Janet Reno vacated the decision and remanded the case back to the BIA, pending the Department of Justice issuing a proposed rule on asylum and domestic violence. Reno, however, left office and the case was handed to John Ashcroft who also failed to decide on Alvarado's case and never made a final proposed rule. Altogether, Alvarado's case sat in the hands of three different Attorney Generals (AG) without a final ruling, until the Obama administration granted her asylum in 2009. ${ }^{15}$

Although Ms. Alvarado suffered through years of legal uncertainty on top of ten years of violent abuse at the hands of her husband, she is one of the luckier ones. Case summaries posted on the Center for Gender and Refugee 
Studies website indicate a number of domestic violenceasylum petitions having been denied despite the viciousness of the attacks on the women and the clear human rights violations. One such case concerns a Pakistani woman whose suffering most people would agree is extraordinary. Not only did the husband regularly beat her, including shortly after she had given birth, but she also had to ward off sexual advances made by her father-inlaw. Her mother-in-law, in the meantime, did nothing to assist her and in fact, further urged the husband to beat her. Even after the woman divorced her husband, her ex-husband arranged for two policemen to rape her for several hours while he and the mother-in-law watched and egged on the officials. Her case was reported in the local newspapers, investigated by Amnesty International, and even received attention from the then Prime Minister Benazir Bhutto, and yet she was denied asylum in the United States. ${ }^{16}$

The lack of predictability in gender asylum cases can be attributed to several factors. First, the gender guidelines are not policies or regulations so there is no one standard; officers and judges decide cases based on their own judgment and interpretation. Case law certainly helps, but it does not guarantee consistent outcomes. Second, while officers and judges are encouraged to be sensitive to gender issues, they must do so "within the [existing] framework," which is difficult because the structure was created with no mention or recognition of women and their unique experiences in the original definition of a refugee. ${ }^{17}$ Third, neither Congress nor INS have given specific directions on exactly how female genital mutilation, forced marriage, and domestic violence, for example, qualifies as persecution based on race, religion, nationality, membership of a particular social group or political opinion. As a result, attorneys and petitioners have been trying to find the best way to fit their case into the existing categories. A frequently successful approach has been to argue gender-based persecution claims un- 
der the "particular social group" and "political opinion" categories, but who constitutes a social group and what is a legitimate political opinion are still highly contested by immigration judges and members of the BIA. ${ }^{18}$

In 2002, for example, M-L-C- petitioned for asylum having been persecuted as a member of a particular social group: she was a victim of forced marriage. M-L$\mathrm{C}$ - is a young Chinese woman who was forcibly sold to the village director for the purposes of marriage by her father. At first she refused to comply with her father's wishes, and was beaten and imprisoned for three days without food or water. Afterwards, the village director kidnapped her, coerced her to participate in a wedding ceremony and then raped her. Later that very night, $M$ $\mathrm{L}-\mathrm{C}$ - escaped and made her way to the United States. During her hearing, M-L-C- argued that she met the definition of a refugee by having "suffered past persecution on account of her membership in the social group of Chinese women who have been forced through physical and sexual abuse into marriage, and who live in a part of China where forced marriage is considered valid and enforceable by the governing authorities." 19

The IJ rejected this argument in spite of the fact that seventeen years earlier, the BIA had established an interpretation of "membership in a particular social group" that could include women (Matter of Acosta). Members of a social group, according to the decision, must "share a common, immutable characteristic, i.e., a characteristic that either is beyond the power of the individual members of the group to change or is so fundamental to their identities or consciences that it ought not be required to be changed." This case, then, made it possible to view sex as an immutable characteristic. ${ }^{20}$

While it appears that the IJ ignored the BIA's decision, it must be recognized that the guidance given in Acosta is "incomplete," according to legal scholar T. David Parish. There is still plenty of murkiness in the definition; Acosta "sets an outer limit, [but] it fails to describe the 
characteristics by which a cognizable social group may be recognized as such." 21 So even with Acosta, a judge can apply their own interpretation and apparently, the IJ did not believe that M-L-C's characteristics-that of being a Chinese woman who had been sold into marriage-was immutable enough.

The "incompleteness" of Acosta, however, became a favorable condition for Hong Ying Gao just four years later in 2006. Her case, Gao v. Gonzales, was hauntingly similar to M-L-C-. Gao, like M-L-C-, had been sold to a local man by her father and went to live with her future spouse, Chen Zhi. Upon arrival, she found him to be "bad-tempered" and physically abusive and "when Gao tried to break their engagement," according to case records, "Zhi threatened her" and warned that his uncle, "a powerful local official, would arrest her." Gao had heard that Zhi's uncle did arrest people for "personal reasons," so the threat seemed quite possible. Gao escaped from Zhi and moved an hour away by boat, but he harassed her family and eventually found her. Gao realized that her only hope was to leave China altogether. ${ }^{22}$ In contrast to M-L-C-, the Second Circuit took the definition of a social group from Acosta and found Gao to be a part of a group of "women who have been sold into marriage (whether or not that marriage has yet taken place) and who live in a part of China where forced marriages are considered valid and enforceable."23 This ruling did not mean that all women in China were automatically eligible for asylum, but coupled with the fact that the Chinese government was unable to protect Gao from forced marriage, and that she could not relocate anywhere else in China without being in danger, altogether served to satisfy asylum requirements.

Gao v. Gonzales became an important landmark case that widened the definition of a "particular social group" and has had a significant impact on women's opportunities for asylum. It is important to note, however, that in spite of its success, this decision has only opened the 
door for women who are or have been sold into marriage, not any other situation. It will take more case law to truly expand the category for women who are persecuted on other (gender-based) grounds.

The fact that the asylum process must continuously be amended to recognize the specific needs and experiences of women means advancement will take time. Some scholars, however, believe it will take more than time, but a serious paradigm shift; from a male-oriented system (often described as gender-blind or neutral) to a system of gender equality. According to these scholars, not only is the original framework organized around the experiences of men, but the process is often adjudicated by men (and women) who fear or are resistant to fundamentally changing the current system. Regardless of what they fear, the asylum process is, as Jane Freedman argues, "undermined by deeply gendered practices," or worst, as Connie Oxford explains, a "gender regime structures asylum practices." 24

Manifestations of how asylum is either structured or undermined by gendered practices is most evident in the way that INS (now called USCIS, United States Citizenship and Immigration Services) must constantly develop new guidelines and case law to accommodate women's experiences. The original framing of the asylum law was based on the experiences of men, which were considered to be the "norm." Women's experiences tended to be seen as outside of immigration law or rendered invisible. Male-oriented notions of who is a political agent and what encompasses political opinion pervaded the process and severely limited women's chances because they were not recognized as political agents. ${ }^{25}$ Historically states, like the United States, have recognized the overt (public) political activities of men as being vulnerable to persecution by ruling governments. In contrast, women's activities have often been dismissed because they are not public, but hidden and indirect, such as refusing forced marriage or resisting rape. 
Furthermore, there is evidence that some officers and judges do not recognize certain forms of violence against women as ever reaching the level of persecution. Connie Oxford, in her work on gender-based asylum, presents a horrifying quote from an immigration attorney who found some judges did not consider rape a political act under any circumstances. "We would present evidence about women who were raped by Haitian soldiers and how the military is used in Haiti," stated the attorney, "but the gut reaction of the immigration court of the BIA or the circuit court was that it's personal, it's a terrible thing, but it's a personal problem, you're a victim of crime."26 In other words, sexual violence, regardless of the persecutor or his motivations, is considered to be a "private" matter.

This reluctance or refusal to see women who are attacked within the private realm as "targets of persecution" is not solely the fault of individual judges, however. Traditionally, matters within the family and private sphere, including abuse, were considered beyond the scope of a state's powers. ${ }^{27}$ Many governments, including the United States, were (and to some extent still are) hesitant to "interfere" and adjudicate in matters that do not directly involve the state claiming there is a divide between the private and the public that cannot be breached. ${ }^{28}$ As Kathryn Libal and Serena Parekh explain:

Human rights discourse, since its modern beginnings in the $17^{\text {th }}$ century, has been predicated on the division between the public and private realm. This division separates the realm of the political, the government or state, and the economy from the real of the household, the family and private affairs. The private realm was largely considered apolitical; it was thought to be devoid of power relations... ${ }^{29}$

Over the past century, the work of feminists, activists, and women who have been victimized, has significantly 
helped move the state into the private sphere. The fruit of their efforts can be seen in the declarations made by the U.N. such as the "Convention on the Elimination of All Forms of Discrimination Against Women" (CEDAW). CEDAW adopted in 1979, has been dubbed as the international bill of rights for women and urges all signers to "ensure elimination of all acts of discrimination against women by persons, organizations or enterprises," with no distinctions made between the public and private realms. ${ }^{30}$ This momentous document was followed by additional guidelines released in 1985 and 1991 by the United Nations High Commissioner of Human Rights that identified refugee women and girls as experiencing "special problems" resulting from sexual and physical abuse, exploitation and sexual harassment and called for reorienting "existing programmes" to address them. ${ }^{31}$

The expansion of American case law to recognize gender-based asylum, though uneven, is yet another example of eliminating the private/public division. But there are indications that the U.S. government is still uncertain when acts of violence move from the private to the public sphere and become acts of persecution. The INS 1995 gender guidelines discussing domestic violence, for example, specify that it "cannot be purely personal... The harm feared must rise to the level of persecution... [that] denotes extreme conduct and does not include every sort of treatment our society regards as offensive, unfair, unjust, or even unlawful or unconstitutional...." And finally, "In order for an applicant to meet the definition of a refugee she must do more than show a well-founded fear of persecution in a particular place or abode within a 'country' - she must show that the threat of persecution exists for her country-wide... ${ }^{32}$

One way officers and judges measure if the violence goes beyond being offensive or illegal is by examining the impact it has had on the petitioner. More specifically, judges are looking for the extent of suffering, and/or the petitioner's refusal to conform or submit to the harm as 
an indication of whether the harm has reached a level of persecution. Many scholars have been quick to note how this standard discriminates against women who do not or cannot show the level of suffering judges are expecting. As Helen Grant points out, "a woman who suffers psychological abuse alone, who suffers minor physical abuse at the hands of a husband, or who is required to conform to his ideals without an overriding threat of serious physical harm will be unable to successfully seek asylum and avoid deportation under U.S. asylum law."33

The adjudicators' demands for proof of severe harm and suffering reveal more than a limited method of separating acts of crime from persecution, they also demonstrate ethnocentric and racially gendered attitudes. The proof demanded is generally based on white western cultural standards of how people (e.g. men) should behave towards maltreatment. Behaviors that fall below these standards are considered suspect or worst, they become proof that no violence has occurred at all. Women from non-western countries are at a profound disadvantage because they were socialized to respond in culturally specific ways that are not like how white Americans would behave. As a result, women from Asia, Africa, Central and South America find themselves being doubly harmed: at the hands of their persecutors and at the hands of the U.S. asylum system. ${ }^{34}$

Yan Xian Zhu, for example, suffered great humiliation, shame and physical harm as a result of being beaten unconscious and raped by her boss back in China. Her sense of humiliation was no doubt heightened when the IJ rejected her testimony based on the fact that she did not seek medical help immediately after being assaulted. Though Zhu explained she did not contact a doctor because she felt shame and that her "mother also told [her] what happened to her was 'shameful to us [parents]," " the judge responded that the petitioner's reason was "obviously the testimony of someone who has never been knocked unconscious, nor raped."35 The judge had 
no sense about or sensitivity to how patriarchal ideology in China controls women's behavior and political power by forcing them to keep silent about sexual abuse and exploitation. The judge also had no understanding of how, in many Asian countries, the entire family can reinforce the subordination of women by demanding she not publicize her harms or else she will bring shame to all of them. ${ }^{36}$

Su Chun Hu was also scoffed by an IJ after she described having been forced to undergo an abortion by Chinese government officials. After hearing her testimony, the IJ accused Su Chun Hu as being "someone who has never experienced an abortion procedure and [that it] was more akin to a routine gynecological 'pap smear' check-up, rather than a life-altering traumatic experience" based on the mere "demeanor and the timbre of her voice."37

A similar situation happened to another Chinese applicant when she disclosed she had been forced to undergo four abortions. Apparently she did not "behave" within the norms of western cultural ways. In the oral decision, quoted by Connie Oxford in her work, the judge declared, "The Court finds it incredible that the applicant had four abortions. The Court does not believe that any woman would suffer through four abortions. The Court believes that this woman would say anything to remain in the country." 38

At the same time that judges and officials demand that female petitioners behave and respond in ways familiar to their western sensibilities, they conversely require a non-western cultural explanation for the actions of the persecutors. In other words, adjudicators are more likely to find the petitioner believable if their stereotyped, cultural assumptions about non-western countries and how they treat women are confirmed. Anita Sinha, in her examination of asylum cases, makes an even stronger argument, "Asylum applicants who flee from non-Western countries because of gender-related violence find that 
their cases often turn on whether they can show that the persecution they suffered is attributable to the cultural 'backwardness' of their home countries."39

Sinha comes to this conclusion through her examination of In re Kasinga (a case concerning FGM) and In re $R$ - $A$ - (a case concerning domestic violence). In the former case, which was successful in a timely fashion, she finds that references to female genital mutilation were consistently associated with the term "practice" or "tribal custom" thereby linking the violence against Kasinga to a cultural ritual rather than a form of violence against women to control their sexuality. Moreover, Sinha believes that the indictment of the Togo culture helped Kasinga's case, whereas Alvarado (In re $R$-A-) was less successful because judges did not find domestic violence alone (e.g. no "culture hook") to be a compelling argument. ${ }^{40}$

The officers and judges' approval of cultural explanations for harm and persecution has not been lost on petitioners and their attorneys. The attorney for the case of "Client," a Mongolian woman petitioner, included cultural data to demonstrate the status of women in that country. The brief for this case included the proverb, "If a husband does not beat his wife once a month, he is not a man," and a quote from the United Nations, "women are slaves for men and servants for the home," to show the connection between the Mongolian culture and the abuse of women. ${ }^{41}$ In Gao v. Gonzales, the record indicates that Gao's abuse is because of customary practices in China where "parents routinely sell their daughters into marriage."42

Another immigration attorney interviewed for this article explained that he too provided information about the respondent's culture and country of origin to help explain the context of her persecution. In his two cases involving "honor killings," where the death of the female is required to restore honor to the family, he utilized materials from the U.S. State Department and human rights organizations to support his case. A quick examination of 
the State Department and Amnesty International's materials concerning Pakistan (one of the respondent's country of origin), yields authoritative-sounding information on the poor human rights record in that country and the traditions and "tribal culture" that is the supposed basis for these killings. ${ }^{43}$

Perhaps even more astonishing are the instances when petitioners are encouraged to structure their applications on claims that exploit the "cultural hook." Oxford, in her interviews with petitioners, found they had been persuaded by attorneys and service providers to discuss their experiences with forced circumcisions instead of the non-FGM reasons that had prompted them to flee. The attorneys believed the petitioners' cases would be better received if they exploited the fact that the women had been circumcised because judges seem to agree that the procedure constituted persecution. ${ }^{44}$

The role that officers, judges, the BIA, attorneys and even petitioners play in perpetuating ethnocentric and racialized gendered practices in the asylum process is quite apparent. The dangers of essentializing and "othering" non-western cultures and demanding petitioners present themselves as "worthy" victims are just as clear. And the calls from scholars, attorneys and activists to end such practices are urgent and understandable; but uprooting or correcting these biases is not, however, simple.

To begin with, the entire premise behind granting asylum is based on a foundation of difference. By asking for a haven from persecution, the petitioner is immediately perceived as valuing the United States as being a "more enlightened" place (whether they believe it or not) than their country of origin, which automatically reinforces older notions of America as a strong and powerful colonial empire. As Charles Piot explains,

The asylum claim assumes a difference-a cultural difference-between country of origin and host country. Thus the asylum petitioner seeks refuge from barbaric 
customs/irrational sentiments/racist prejudice/totalitarian politics/religious fanaticism. As such the granting of asylum invokes and reinscribes notions of radical cultural alterity that were emblematic of colonial modernity as well as of cold war geopolitics... those that were 'modern' (whether capitalist or socialist) and those more 'traditional'.... ${ }^{45}$

Other social scientists concur and find that the very act of accepting refugees "usually implies condemnation of the relevant government for persecuting its citizens, or at least failing to afford them protection." 46 The U.S. government is not blind to the signal that asylum sends. During the Cold War in the 1950s, for example, America's refugee program gave high priority to individuals escaping from communist nations and it was not just for humanitarian reasons. As political scientists Salehyan and Rosenblum explain, "the United States readily accepted [these] refugees...as a way to discredit these regimes, drain them of human resources, and promote opposition activities." 47

At the very heart of asylum claims is the reinscription of differences between the host and country of origin, but a great deal of those differences were constructed centuries ago with the myth of American Exceptionalism, that predates legal asylum. This myth is based on the view of America as distinct, unique, free from the corruption and decay of the old world, and free from the confines and persecutions of hierarchical societies and governments, which has been circulating since Europeans started settling the land. Philosophers and travelers from the 1700s and 1800s often proclaimed the new world to be an asylum from tyranny and nepotism of the old world and ripe for a social revolution. ${ }^{48}$

Claims for American Exceptionalism also include that the "United States has a unique place in history, differing fundamentally and qualitatively from all other countries" and that it has a "'God-given destiny' to guide the 
rest of the world."49 The claim of being a "civilized" country in comparison to the rest of the world has been a part of the foundational narrative from the start and has been embedded in every policy concerning American expansionism, efforts to spread democracy, international policing activities, and the war against terrorism.

Embedded in this "God-given destiny" are also notions of racialized moral superiority. This sentiment can be read in John Winthrop's belief that God wanted the English colonists to control the lands inhabited by Indians: "For the natives, they are near all dead of the smallpox, so the Lord hath cleared our title to what we possess." 50 This sense of superiority can also be found in the discussions surrounding the U.S. colonization of the Philippines; government officials, including presidents, justified controlling the islands stating that it was their duty to "civilize" and "uplift" Filipinos. ${ }^{51}$ A more recent reference can be found in George W. Bush's explanation of 9/11 to the press, "I see things this way: The people who did this act on America and who may be planning further acts are evil people. They don't represent an ideology; they don't represent a legitimate political group of people. They're flat evil. That's all they can think about, is evil. And as a nation of good folks, we're going to hunt them down and we're going to find them, and we will bring them to justice." 52 Though Bush did not ascribe a race or color to this "evil" group, by September $12^{\text {th }}$, most of American media had already identified the terrorists to be connected with radical Islamic groups and/or from the Middle East. It is easy to surmise from Bush's comments, then, that we, "good folks" are opposites to, and better than, the darker-skinned, non-Christian "evil" people.

Within this broader context of American Exceptionalism and its impact on the society and politics, the ethnocentric and racialized gendered aspects of the asylum process can be seen as manifestations of that foundational narrative. The original asylum definition as well as all newer guidelines and recent case law were never meant 
to disrupt that claim; in fact, they were created imbued with a sense of American superiority complete with its ideals about race and gender.

Even with the advancements in gender-related asylum practices, such as In re $R-A-$, racialized political and cultural concerns still feature prominently in the refugee process. It appears that judges and officers have concerns that go beyond the applicant's circumstances. A study in 2004 by Rosenblum and Salehyan, for example, finds strong evidence that "non-ideational interests" temper human rights concerns in asylum cases. They found that "US asylum enforcement has consistently taken account of the level of democracy in applicants' countries of origin," as part of their decision to approve, or not, the petitioner's request. Similarly, the 2009 study by Andy Rottman, et al, presents persuasive evidence that asylum officers have been affected by the events of $9 / 11$ and have been "more apt to deny claims after 2001" for fear of future attacks on US soil. ${ }^{53}$

Gender-related asylum cases have also been affected by concerns that go beyond confirming whether an applicant is eligible or not. During this climate of antiimmigrant sentiment, fears about national security, job protection, and increasing social welfare costs, have prompted officers and judges to wonder if they are opening the "floodgates" with each woman they admit. This argument, as described by Helen Grant, is the belief that "to recognize women as a social group and domestic violence as persecution" would "open the floodgates to these types of claims." As the argument goes, petitioners would fraudulently claim their husbands beat them in order to gain entry, which would overwhelm immigration officers and end up closing the borders to people who need protection. ${ }^{54}$ While this argument may sound overly dramatic, it cannot be dismissed. Three different asylum attorneys contacted for this study all agreed that judges are thinking about the "floodgates" when adjudicating gender-based persecution cases and that it is a 
factor they must account for in their arguments on behalf of the respondents. As a result, each attorney carefully frames the applicant's situation to emphasize the gravity of her situation, which includes lengthy discussions of culturally-based discriminatory gender practices that occur in their country of origin.

There are many drawbacks and caveats to the present (and slowly changing) gender-based asylum process. Some critics believe the recent successful cases do not educate officers, judges and the public about the broader factors that encourage and support violence against women-such as patriarchy--and sadly reinforce neoOrientalist notions about non-western cultures. Other critics believe this very approach is dangerous not for its colonialist ideas, but for setting a negative precedence for future petitions. In contrast to cases of FGM, women who are fleeing forced detention, torture, or the denial to gain an education may not qualify for asylum because their cases may not seem "exotic" enough or lack the "cultural hook." Furthermore, asylum case law will never be exempt from the all-consuming interests about national security, job protection, and conservative social concerns. They will continue to be affected by racialized gender practices and beliefs about American Exceptionalism that pervade this country. And last, but not least, the prejudices and biases that affect asylum officers and judges will not necessarily disappear.

The solutions to most of these concerns are not forthcoming. All scholars and attorneys who write about gender-based asylum all hope for a process that is less ethnocentric, provides greater gender equality and is more sensitive to the needs of the petitioner instead of other concerns. Yet, there appears little incentive on part of those who control immigration to change so radically. Change might only happen with each new legal success, but very slowly and with great limitations.

In view of these factors, when I hear of individuals like Vallabhaneni, Zhu, Alvarado, and Kasinga, my concerns- 
the ones I raised in the beginning of this article--seem rather selfish and whiney. These are women who have struggled hard to find safety and to rebuild their lives by whatever means were available to them. Who am I to be critical of their cases or their methods? Haven't they been persecuted enough by both their abusers and the asylum system? Isn't it enough that the asylum process can and will save the lives of some women?

Further, the asylum process does not seem like the "front line" to changing deep-seated beliefs in moral and racial superiority. At this very moment, the "front line" is in New York where public outcry is trying to prevent an Islamic Community Center from opening near "Ground Zero," and in Gainesville, Florida, where the Dove World Outreach Center proposes to burn Qurans in a public bonfire. ${ }^{55}$ And yet, these two places are integrally tied to the process of asylum by fear and nationalism guided by racism. The very basis on which America opens its doors to abused women of different faiths, political beliefs, and nationalities, also undergirds the racial, cultural, and religious hostility that pervades the country. As a result, the asylum process is a good place to start.

By highlighting the consequences of adjudicating petitions under a gender regime and through the cultural lens of Orientalism and American Exceptionalism, I am drawing a new line. Cultural stereotypes cannot be the basis for asylum decisions. The dependency on stereotypes narrows case law and policies for asylum based on gender-related persecution; petitioners, like Alvarado, who lack the "culture hook" are at great risk of being deported. Furthermore, stereotypes obscure the true nature of violence against women. Gendered power arrangements, not traditional family customs, enabled Gao to sell his daughter into marriage; culture may socially and legally sanction the practice, but it is not the source. ${ }^{56}$ Last, but not least, ending the use of cultural stereotypes might help create a process that is based on gender justice, not on narratives of difference and supposed "infe- 
riority," and perhaps then my students will have a more sophisticated critique about immigration and asylum that restores agency to the petitioner and moves away from America the savior.

\section{Endnotes}

1 Edward Said, Orientalism, (New York: Vintage Books, 1979); Meghana V. Nayak and Christopher Malone, "American Orientalism and American Exceptionalism: A Critical Rethinking of U.S. Hegemony," International Studies Review 11, (2009): 254.

2 Brief for Nancy Kelly et al as Amicus Curiae Supporting Respondents, In the Matter of Aruna C. Vallabhaneni, (B.I.A., 2002), http://www.gbls.org/immigration/ RAAMICUSSUPPORTVAL.PDF.

3 Fauziya Kasinga's name is actually spelled Kassindja. This article uses the name as written in the court records, though.

4 In re Fauziya Kasinga, 21 I\&N Dec. 357 (B.I.A. 1996).

5 Displaced Persons Act of 1948, Pub. Law No. 80-774, 62 Stat. 109.

6 Convention Relating to the Status of Refugees, July 28 , 1951, 189 U.N.T.S. 137 http://www.unhcr.org/refworld/ docid/3b01b964.html; Protocol Relating to the Status of Refugees, Jan. 31, 1967, http://www2.ohchr.org/english/ law/protocolrefugees.htm

7 Maureen O'Connor Hurley, “The Asylum Process: Past, Present, and Future," New England Law Review 26, (1992): 1003.

8 U.S. Library of Congress. Congressional Research Service. May 5, 2005. U.S. Immigration Policy on Asylum Seekers for Congress, May 5, 2005, by Ruth Ellen Wasem. RL32621. Washington, D.C.: Government Printing Office. http:// www.fas.org/sgp/crs/misc/RL32621.pdf: Refugee Act of 1980, Public Law 96-212, 96h Cong. (17 May 1980). Refugee Act of 1980. Law 96-212. 94 Stat. 102.

9 U.S. Government Accountability Office. Sep. 2008. U.S. Asylum System: Significant Variation Existed In Asylum Outcomes across Immigration Courts and Judges. http: / / www.gao. gov/new.items/d08940.pdf.

10 This change followed after several important international policies concerning gender had been passed by the United Nations and by Canada. See United Nations High Commissioner for Refugees, Refugee Women and International Protection, Executive Committee Conclusion 39, (18 October 1985) http://www.unhcr.org/cgi-bin/ texis/vtx/search?page=search\&docid=3ae68c43a8\&query 
=refugee woman 1985; United Nations High Commissioner for Refugees, Guidelines on the Protection of Refugee Women, (June 1991); http://www.icva.ch/doc00000822. html; Canadian Immigration and Refugee Board, Guidelines on Women Refugee Claimants Fearing Gender-Related Persecution, (Mar. 9 1993).

11 U.S. Department of Justice. Office of International Affairs. May 26, 1995. Consideration for Adjudicating Claims from Women, May 26, 1995, by Phyllis Coven. Washington, D.C.: Government Printing Office; http://www.state. gov/s/l/65633.htm; American Immigration Lawyers Association, "INS Asylum Gender Guidelines: Fact Sheet May 26, 1995," <http://www.aila.org/content/default. aspx?bc $=20130 \% 7$ C13813 > (2 Aug., 2010); Karen Musalo and Stephen Knight, "Steps Forward and Steps Back: Uneven Progress in the Law of Social Group and Gender Based Claims in the United States," International Journal of Refugee Law, 51 (2000): 5.

12 In re Fauziya Kasinga, 21 I\&N Dec. 357 (B.I.A. 1996).

13 In re X-P-T-, Interim Decision \#3299 (B.I.A. 1996).

14 In re R-A-, 23 I\&N Dec. 694 (A.G. 2005).

15 Helen P. Grant, "The Floodgates Are Not Going To Open, But Will The U.S. Border?" Houston Journal of International Law 29, no. 1 (Nov 2006): 4; In re R-A-, 23 I\&N Dec. 694 (A.G. 2005).

16 Center for Gender and Refugee Studies, Gender Asylum Case Summary No.131 <http://cgrs.uchastings.edu/law/detail. php> (2 Aug., 2010).

17 U.S. Department of Justice. Office of International Affairs. May 26, 1995. Considerations for Asylum Officers Adjudicating Claims from Women, May 26, 1995, by Phyllis Coven. Washington, D.C.: Government Printing Office; http:// www.state.gov/s/l/65633.htm; Connie G. Oxford, "Protectors and Victims in the Gender Regime of Asylum," NWSA Journal 17, no. 3(Fall, 2005): 18; Sara L. Zeigler and Kendra B. Stewart, "Positioning Women's Rights within Asylum Policy," Frontiers 30, no.2 (2009): 116.

18 Crystal Doyle, “Isn't 'Persecution' Enough? Redefining the Refugee Definition to Provide Greater Asylum Protection to Victims of Gender-Based Persecution," Washington and Lee Journal of Civil Rights and Social Justice 15 (2008-2009): 548.

19 World Organization for Human Rights USA: “Miya." http://www. humanrightsusa.org/index.php?option-com_content\&task=v iew\&id $=173 \&$ Itemid $=140$.

20 Matter of Acosta, A-24159781, (BIA, 1 Mar., 1985). 
21 T. David Parish, "Membership in a Particular Social Group Under the Refugee Act of 1980: Social Identity and the Legal Concept of a Refugee," Columbia Law Review 92, no. 4 (May, 1992): 939.

22 Gao v. Gonzales, 440 F. 3d 62 (2006).

23 Ibid.

24 Jane Freedman, "Protecting Women Asylum Seekers and Refugees: From International Norms To National

Protection?" International Migration 48, no. 1 (2009): 177;

Connie G. Oxford, "Protectors and Victims," 30

25 Helen P. Grant, “The Floodgates Are Not Going To Open," 9.

26 Connie G. Oxford, "Protectors and Victims," 30.

27 Jacqueline Bhabha, "Demography and Rights: Women, Children and Access to Asylum," Journal of International Refugee Law 16, no. 1 (2004): 228; Ronagh J.A. McQuigg, "How Could Human Rights Law Be Used By the Courts to Assist Victims of Domestic Violence? A Comparative Study," The International Journal of Human Rights 14, no. 3 (May 2010): 344 .

28 The United States, as of 2009, has not ratified CEDAW.

29 Kathryn Libal and Serena Parekh, "Reframing Violence Against Women as a Human Rights Violation: Evan Stark's Coercive Control," Violence Against Women 15, no. 12 (2009): 1480. See also: Rebecca Hulse, "Privacy and Domestic Violence in Court," William \& Mary Journal of Women and the Law 16, iss. 2 (Winter 2010): 237-290; Susaane Baer, “A Closer Look at Law: Human Rights as Multi-Level Sites of Struggles Over Multi-Dimensional Equality," Utrecht Law Review 16, iss. 2 (June 2010): 56-76; Frances Raday, "Privatizing Human Rights and the Abuse of Power," Canadian Journal of Law and Jurisprudence 13, iss. 3 (2005): 295-304; Karen Engle, "After the Collapse of the Public/Private Distinction: Strategizing Women's Rights," Studies in Transnational Legal Policy 25, (1993): 143-56.

30 Convention on the Elimination of all Forms of Discrimination against Women, Dec. 18, 1979, 1249 U.N.T.S. 13 http:// www2.ohchr.org/english/law/cedaw.htm.

31 United Nations High Commissioner for Refugees, Refugee Women and International Protection, Executive Committee Conclusion 39, (18 October 1985); http: / /www.unhcr. org/cgi-bin/texis/vtx/search?page=search\&docid=3ae68 c43a8\&query=refugee women 1985; United Nations High Commissioner for Refugees, Guidelines on the Protection of Refugee Women, (June 1991): http: / /www.icva/ch/ doc00000822.html. 
32 American Immigration Lawyers Association, "INS Asylum Gender Guidelines: Fact Sheet May 26, 1995," <http://www.aila. org/content/default.aspx?bc $=20130 \% 7$ C13813> (2 Aug., 2010)

33 Helen Grant, 17.

34 Jane Freedman, 183.

35 Yan Xian Zhu v. Mukasey, No. 06-72967, (9 $9^{\text {th }}$ Cir., 2006); Yan Xia Zhu v. Mukasey 537 F. 3d 1034 (9 ${ }^{\text {th }}$ Cir., 2008).

36 Elizabeth Midlarsky, Anitha Venkataramani-Kothoari, and Maura Plante, "Domestic Violence in the Chinese and South Asian Immigrant Communities," Annals of the New York Academy of Sciences, (2006): 287; M.R. Yoshioka and D.Y. Choi, "Culture and Interpersonal Violence Research," Journal of Interpersonal Violence 20 (2005): 513-19.

37 Su Chun Hu v. Eric H. Holder, Jr., 08-2998-ag (Aug 2008).

38 Connie Oxford, 34.

39 Anita Sinha, "Domestic Violence and U.S. Asylum Law:

Eliminating the 'Cultural Hook' for Claims Involving Gender-

Related Persecution," New York University Law Review 76 (Oct 2001): 1578.

40 lbid., 1584 \& 1598.

41 Brief in Support of Client's Affirmative Application for Asylum, Client, from personal records.

42 Gao v. Gonzales, 440 F 3d 62 ( $2^{\text {nd }}$ Cir., 2006).

43 Amnesty International, "Pakistan: Honour Killings of Girls and Women," Index Number ASA 33/018/1999, (31, Aug., 1999): 4; U.S. Department of State, Bureau of Democracy, Human Rights and Labor, "2009 Country Reports on Human Rights Practices," 11, Mar., 2010 <http://www.state.gov/g/drl/ rls/hrrpt/2009/sca/136092.htm> (30 Aug., 2010).

44 Connie Oxford, 29.

45 Charles Piot, "Asylum and Culture: Comments on Khanna and Noll," Texas International Law Journal 41 (2006): 504.

46 Aristide R. Zolberg, Astri Suhrke, Sergio Aguayo, "International Factors in the Formation of Refugee Movements," International Migration Review 20, no. 2 (Summer, 1986): 155.

47 Idean Salehyan and Marc. R. Rosenblum, "International Relations, Domestic Politics, and Asylum Admissions in the United States," Political Research Quarterly 61, no. 1 (Mar., 2008): 105.

48 Joyce Appleby, "Recovering America's Historic Diversity: Beyond Exceptionalism," The Journal of American History 79, no. 2 (Sept., 1992): 419. (419-31); Alexis de Tocqueville, “Author's Introduction," Democracy in America, <http:// 
xroads.virginia.edu/ HYPER/DETOC/toc_indx.html> $(31$ Aug., 2010).

49 Meghana V. Nayak and Christopher Malone, "American

Orientalism and American Exceptionalism: A Critical Rethinking of U.S. Hegemony," International Studies Review 11 (2009): 254 (253-276)

50 John Winthrop, "Mounting Conflict With Native Americans," 1634, Digital History, <http: / /www.digitalhistory.uh.edu/ documents/documents_p2.cfm?doc-203> (1 Sept., 2010)

51 James A. Tyner, "The Geopolitics of Eugenics and the Exclusion of Philippine Immigrants from the United States," Geographical Review 89, no. 1 (Jan., 1999): 54-73; A. Stephanson, Manifest Destiny: American Expansionism and the Empire of Right, (New York: Hill and Wang, 1995).

52 George W. Bush, "Remarks to Federal Bureau of Investigation Employees, September 25, 2001," Weekly Compilation of Presidential Documents, Office of the Federal Register, National Archives and Records Administration, (Washington, D.C., 1 Oct., 2001): 1375; Robert G. Patman, "Globalisation, the New US Exceptionalism and the War on Terror," Third World Quarterly 27, no. 6 (2006): 972-3 (963986.)

53 Andy J. Rottman, Christopher J. Fariss, and Steven C. Poe, "The Path to Asylum in the US and the Determinants for Who Get In and Why?" International Migration Review 43, no. 1 (Spring 2009): 29.

54 Helen Grant, 5.

55 Jon Cohen and Kyle Dropp, "Most Americans Object to Planned Islamic Center near Ground Zero, Poll Finds," Washington Post , 8 Sept 2010, <http://www. washingtonpost.com/ wp-dyn/content/article/2010/09/08/AR2010090806231. html?hpid=topnews> (8 Sept 2010); Valerie Bauerlein and Farnaz Fassihi, "Pastor, Despite Protests, Still Plans Quran Burning," Wall Street Journal, 8 Sept 2010, <http://online. wsj.com/article/SB1000142405274870345380457547957364 9222094.html> (8 Sept 2010)

56 Jeff Hearn and Linda McKie, "Gendered and Social Hierarchies in Problem Representation and Policy Processes: 'Domestic Violence' in Finland and Scotland," Violence Against Women 16, no. 2 (8 Dec 2009): 136-58. 


\section{Bibliography}

American Immigration Lawyers Association, "INS Asylum Gender Guidelines: Fact Sheet May 26, 1995." Accessed August 2, 2010, http://www.aila.org/content/default. aspx?bc=20130\%7C13813.

Amnesty International, "Pakistan: Honour Killings of Girls and Women," Index Number ASA 33/018/1999, 31, Aug., 1999.

Appleby, Joyce. "Recovering America's Historic Diversity: Beyond Exceptionalism." The Journal of American History 79, no. 2 (Sept., 1992): 419-31.

Bauerlein, Valerie and Farnaz Fassihi. "Pastor, Despite Protests, Still Plans Quran Burning." Wall Street Journal. September 8, 2010. http://online.wsj. com/article/SB10001424052748703453804575479 573649222094.html.

Bhabha, Jacqueline. "Demography and Rights: Women, Children and Access to Asylum." Journal of International Refugee Law 16, no. 1 (2004): 227-43.

Canadian Immigration and Refugee Board, Guidelines on Women Refugee Claimants Fearing Gender-Related Persecution, (Mar. 9 1993).

Center for Gender and Refugee Studies. Gender Asylum Case Summary No.131. Accessed August 2, 2010. http://cgrs.uchastings.edu/law/detail.php.

Cohen, Jon and Kyle Dropp. "Most Americans Object to Planned Islamic Center near Ground Zero, Poll Finds." Washington Post, September 8, 2010. http://www.washingtonpost.com/wp-dyn/ content/article/2010/09/08/AR201009080631. html?hpid=topnews. 
Convention on the Elimination of all Forms of Discrimination against Women. Dec. 18, 1979, 1249 U.N.T.S. 13 http://www2.ohchr.org/english/law/cedaw. htm.

Convention Relating to the Status of Refugees. July 28, 1951, 189 U.N.T.S. 137 http://www.unhcr.org/refworld/docid/3be01b964.html

Displaced Persons Act of 1948. Public Law 774, $80^{\text {th }}$ Cong. June 25, 1948.

Doyle, Crystal. “Isn't 'Persecution' Enough? Redefining the Refugee Definition To Provide Greater Asylum Protection to Victims of Gender-Based Persecution." Washington and Lee Journal of Civil Rights and Social Justice, 15 (2008-2009): 519-60.

Freedman, Jane. "Protecting Women Asylum Seekers and Refugees: From International Norms to $\mathrm{Na}$ tional Protection?" International Migration 48, no. 1 (2009): 175-98.

Grant, Helen P. "The Floodgates Are Not Going To Open, But Will The U.S. Border?" Houston Journal of International Law 29, no. 1 (Nov 2006): 1-54.

Hearn, Jeff and Linda McKie. "Gendered and Social Hierarchies in Problem Representation and Policy Processes: 'Domestic Violence' in Finland and Scotland." Violence Against Women 16, no. 2 (8 Dec 2009): 136-58.

Hurley, Maureen 0'Connor. "The Asylum Process: Past, Present, and Future," New England Law Review 26, (1992): 995-1049. 
Libal, Kathryn and Serena Parekh. “Reframing Violence Against Women as a Human Rights Violation: Evan Stark's Coercive Control." Violence Against Women 15, no. 12 (2009): 1477-1489.

McQuigg, Ronagh J.A. "How Could Human Rights Law Be Used By the Courts to Assist Victims of Domestic Violence? A Comparative Study," The International Journal of Human Rights 14, no. 3 (May 2010):343363.

Midlarsky, Elizabeth, Anitha Venkataramani-Kothoari, and Maura Plante, "Domestic Violence in the Chinese and South Asian Immigrant Communities." Annals of the New York Academy of Sciences, (2006): 279300.

Miller, Elizabeth, Michele R. Decker, Jay G. Silverman and Anita Raj. "Migration, Sexual Exploitation, and Women's Health." Violence Against Women 13, no. 5 (May 2007): 486-497.

Musalo, Karen and Stephen Knight. "Gender-Based Asylum: An Analysis of Recent Trends." Interpreter Releases 77, no. 42 (Oct 2000): 1533-1543.

Nayak, Meghana V. and Christopher Malone. "American Orientalism and American Exceptionalism: A Critical Rethinking of U.S. Hegemony." International Studies Review 11 (2009): 253-276.

Oxford, Connie G. "Protectors and Victims in the Gender Regime of Asylum." NWSA Journal 17, no. 3 (Fall, 2005):18-38. 
Parish, T. David. "Membership in a Particular Social Group Under the Refuge Act of 1980: Social Identity and the Legal Concept of a Refugee." Columbia Law Review 92, no. 4(May, 1992): 923-953.

Patman, Robert G. "Globalisation, the New US Exceptionalism and the War on Terror." Third World Quarterly 27, no. 6 (2006): 963-86.

Piot, Charles. "Asylum and Culture: Comments on Khanna and Noll." Texas International Law Journal 41 (2006): 503-06.

Protocol Relating to the Status of Refugees. Jan. 31, 1967. http://www2.ohchr.org/english/law/protocolrefugees.htm.

Refugee Act of 1980. Public Law 96-212, 96th Cong. (17 May 1980).

Rottman, Andy J., Christopher J. Fariss, and Steven C. Poe. "The Path to Asylum in the US and the Determinants for Who Get In and Why?" International Migration Review 43, no. 1 (Spring 2009): 3-34.

Said, Edward. Orientalism New York: Vintage Books, 1979.

Salehyan, Idean and Marc. R. Rosenblum, "International Relations, Domestic Politics, and Asylum Admissions in the United States." Political Research Quarterly 61, no. 1 (Mar., 2008): 104-121.

Sinha, Anital. "Domestic Violence and U.S. Asylum Law: Eliminating the 'Cultural Hook' For Claims Involving Gender-Related Persecution." New York University Law Review 76 (2001): 1562-98. 
Stephanson, A. Manifest Destiny: American Expansionism and the Empire of Right. New York: Hill and Wang, 1995.

Toqueville, Alexis de. "Author's Introduction." Democracy in America. Accessed August 8, 2010. http:// xroads.virginia.edu/ HYPER/DETOC/toc_indx. html.

Tyner, James A. "The Geopolitics of Eugenics and the Exclusion of Philippine Immigrants from the United States." Geographical Review 89, no. 1 (Jan., 1999): 54-73.

United Nations High Commissioner for Refugees, Refugee Women and International Protection, Executive Committee Conclusion 39. October, 18, 1985. Accessed August 8, 2010.

http://www.unhcr.org/cgi-bin/texis/vtx/search?page=s earch\&docid=3ae68c43a8\&query=refugee woman 1985.

United Nations High Commissioner for Refugees, Guidelines on the Protection of Refugee Women. June 1991.

U.S. Department of Justice. Office of International Affairs. Consideration for Adjudicating Claims from Women, May 26, 1995, by Phyllis Coven. Washington, D.C.: Government Printing Office; http:/ / www.state.gov/s/l/65633.htm.

U.S. Department of State, Bureau of Democracy, Human Rights and Labor. "2009 Country Reports on Human Rights Practices." Mar., 11 2010. Accessed August 30, 2010. http://www.state.gov/g/drl/rls/ hrrpt/2009/sca/136092.htm. 
U.S. Government Accountability Office. U.S. Asylum System: Significant Variation Existed In Asylum Outcomes across Immigration Courts and Judges. Sep. 2008. Accessed August 8, 2010. http://www.gao. gov/new.items/d08940.pdf.

U.S. Library of Congress. Congressional Research Service. U.S. Immigration Policy on Asylum Seekers for Congress, May 5, 2005, by Ruth Ellen Wasem. RL32621. Washington, D.C.: Government Printing Office. http://www.fas.org/sgp/crs/misc/ RL32621.pdf.

Winthrop, John. "Mounting Conflict With Native Americans." 1634, Digital History. http://www. digitalhistory.uh.edu/documents/documents_ p2.cfm?doc $=203$.

World Organization for Human Rights USA: "Miya."

http: / / www. humanrightsusa.org/indes. php?option=com_content\&task=view\&id $=173$ ltemid $=140$.

Yoshioka, M.R. and D.Y. Choi, "Culture and Interpersonal Violence Research." Journal of Interpersonal Violence, 20 (2005): 513-19.

Zeigler, Sara L. and Kendra B. Stewart. "Positioning Women's Rights Within Asylum Policy: A Feminist Analysis of Political Persecution." Frontiers 30, no. 2 (2009): 115-44.

Zolberg, Aristide R. and Astri Suhrke and Sergio Aguayo. "International Factors in the Formation of Refugee Movements." International Migration Review 20, no. 2 (Summer, 1986): 151-69. 
Ethnic Studies Review Volume 33.1

\section{Court cases:}

Brief for Nancy Kelly et al as Amicus Curiae Supporting Respondents, In the Matter of Aruna C. Vallabhaneni, (B.I.A., 2002). http://www.gbls.org/immigration/ RAAMICUSSUPPORTVAL.PDF.

Gao v. Gonzales, 440 F 3d 62 (2 ${ }^{\text {nd }}$ Cir., 2006).

In re A-V-, (B.I.A. 2002).

In re Fauziya Kasinga, 21 I\&N Dec. 357 (B.I.A. 1996).

In re $M-L-C$ - (B.I.A. 2002). http://www.humanrightsusa. org/indes.php?option=com_content\&task=view\&i $\mathrm{d}=173 \&$ ltemid $=140$.

In re R-A-, 23 I\&N Dec. 694 (A.G. 2005).

In re X-P-T-, Interim Decision \#3299 (B.I.A. 1996).

Matter of Acosta, A-24159781, (BIA, 1 Mar., 1985).

Su Chun Hu v. Eric H. Holder, Jr., 08-2998-ag (Aug 2008).

Yan Xian Zhu v. Mukasey, No. 06-72967, (9th Cir., 2006)

Yan Xia Zhu v. Mukasey 537 F. 3d 1034 (9th Cir., 2008).

\section{Interviews:}

Brief in Support of Client's Affirmative Application for Asylum, "Client," from personal records. 